\author{
Sustinere \\ Journal of Environment and Sustainability \\ Volume 3 Issue 3 (2019) 170-185 \\ Print ISSN: 2549-1245 Online ISSN: 2549-1253 \\ Website: https://sustinerejes.com E-mail: sustinere.jes@iain-surakarta.ac.id
}

\title{
RESEARCH PAPER \\ Pre-treatment potential of electro-coagulation process using aluminum and titanium electrodes for instant coffee processing wastewater
}

\author{
Hoang Quang Huy Phan ${ }^{1}$, Nguyen Xuan Hoan ${ }^{1}$, Nguyen Nhat Huy ${ }^{2}$, Nguyen Duc Dat Duc ${ }^{1}$ \\ Nguyen Thi Ngoc Anh ${ }^{1}$, Nguyen Thi Que ${ }^{1}$, Nguyen Thi Thuy ${ }^{1}{ }^{*}$ \\ ${ }^{1}$ Faculty of Environment - Natural Resources and Climate Change, Ho Chi Minh City University of Food \\ Industry, 140 Le Trong Tan St., Tay Thanh Ward, Tan Phu Dist., Ho Chi Minh City, Vietnam \\ 2 Faculty of Environment and Natural Resource, Ho Chi Minh City University of Technology, VNU-HCM, \\ 268 Ly Thuong Kiet St., Ward 14, Dist. 10, Ho Chi Minh City, Vietnam
}

Article history:

Received 21 August 2019 | Accepted 19 December 2019| Available online 23 December 2019

\begin{abstract}
This study aimed at investigating the potential of electrocoagulation (EC) process using $\mathrm{Al}-\mathrm{Al}$ and $\mathrm{Al}-\mathrm{Ti}$ electrodes for the pre-treatment of instant coffee processing wastewater. Effects of various operating conditions, including cell voltage, time of treatment, inter-electrode distance, $\mathrm{pH}$ of solution, solution conductivity and agitation speed on the removals of chemical oxygen demand (COD) and color were considered. The maximum removal of COD and color was achieved at $87 \%$ and $99 \%$, respectively, corresponding to COD and color in the effluents of 359-384 mg/L and 58-101 Pt-Co. Biodegradability of treated wastewater was significantly improved since $\mathrm{BOD}_{5} / \mathrm{COD}$ increased from initial value of 0.42 to 0.65 after treatment. Nether mixing nor adding of electrolyte was recommended. Moreover, the COD removal kinetics during EC process appeared to follow the first-order kinetic model. The operating costs were also determined as a reference for cost assessment of the treatment.
\end{abstract}

Keywords: Electrocoagulation; Coffee wastewater (CFW); COD removal; Color removal; Operating cost

\section{Introduction}

Coffee processing industry is one of the major agro-based industries in many countries in the world. The coffee industry often requires large quantities of water for various production stages and thus results in the generation of significant amounts of wastewater; for instance, up to 40-45 L of wastewater could be produced per kilogram of coffee (Perez et al., 2000). Coffee wastewater (CFW) normally contains high content of organic compounds and colored matters, including caffeine, fat, peptic substances and many other macromolecules (Kirk et al., 1985;

${ }^{*}$ Corresponding author. E-mail: thuynt@hufi.edu.vn

DOI 10.22515/sustinere.jes.v3i3.87 
Clarke, 2012a; Clarke, 2012b). Therefore, it could possibly cause adverse effects on aquatic fauna and flora as well as downstream communities when released untreated into water bodies. There have been a number of treatment methods developed for remediation of CFW such as chemical coagulation, flocculation, advanced oxidation processes (AOPs) or anaerobic methods (Rattan et al., 2015). Among those, traditional anaerobic systems have been used more popularly but the main drawbacks of this technique relate to slow removal rates and long retention periods, particularly when the presence of slowly biodegradable and non-biodegradable pollutants in CFW is significant.

Electrocoagulation (EC) process has attracted great attention for the treatment of various kinds of wastewater by virtue of various benefits including high treatment and energy efficiency, safety and cost effectiveness (Khandegar \& Saroha, 2013). The advantages of electrocoagulation to compare with conventional coagulation are no addition of chemical, removal of many species that chemical coagulation cannot remove, less sludge, and lower the sludge disposal cost (Khandegar and Saroha, 2013). Some of the limitations of electrocoagulation include the replacement of sacrificial anodes periodically, the resistance to the flow of electric current due to formation of impermeable oxide film, and high cost of electricity (Mollah et al., 2001; Mollah et al., 2004). In EC-based treatment process, when a potential is applied between two electrodes immersed in the wastewater, the metallic anode dissolves into the solution in forms of cationic species which in turn can form metal hydroxides and precipitates under an appropriate $\mathrm{pH}$ condition. The pollutant species then can be adsorbed onto these hydroxides and precipitates (Sahu et al., 2014). So far the EC process has been applied for the treatment of many kinds of industrial wasters, such as tannery and textile industry wastewater (Espinoza-Quinones et al., 2009; Feng et al., 2007; Mountassir et al., 2015), real dyehouse wastewater (Kobya et al., 2016), paper industry wastewater (Zodi et al., 2011), refinery wastewater (Yavuz et al., 2010), Baker's yeast wastewater (Gengec et al., 2012), paint manufacturing company wastewater (Akyol, 2012). However, despite such an intensive amount of research, a few studies have been performed to investigate the applicability of EC process for the treatment of CFW (Mahesh et al., 2014; Asha \& Kumar, 2016; Bui, 2017). Though effect of time and applied voltage on COD, BOD, color, and TDS removal (Mahesh et al., 2014), as well as effect of current density, time of treatment, and $\mathrm{pH}$ on COD removal (Bui, 2017) were investigated, other factors such as interelectro distance, electrolytic concentrations, agitation speed, sedimentation have not been considered comprehensively. As stated earlier, the aluminum and iron electrodes are employed in applications of wastewater treatment either alone or in combination. However, there is a significant amount of $\mathrm{Ca}^{2+}$ or $\mathrm{Mg}^{2+}$ ions in water, inert materials electrodes is recommended (Sahu et al., 2014). In addition, using aluminum and iron electrodes were compared in terms of CFW treatment performance and energy consumption (Mahesh et al., 2014; Asha \& Kumar, 2016; Bui, 2017), but using Ti as cathode replacing for aluminum has not been tested.

The present study investigated the applicability of EC technique for remediation of instant coffee processing wastewater in batch reactor as pre-treatment. The performance of EC-based reactor, in terms of COD and color removal efficiencies, was evaluated with both $\mathrm{Al}-\mathrm{Al}$ and $\mathrm{Al}-\mathrm{Ti}$ electrodes under various operating factors, including the cell voltage, duration time, interelectrode distance, $\mathrm{pH}$ of solution, solution conductivity and agitation speed. COD removal kinetic was then investigated. Moreover, the operating costs for the treatment of coffee wastewater using this technique were also calculated to serve as a reference for economic assessment. 


\section{Experimental}

\subsection{Coffee wastewater sampling}

The instant coffee wastewater was collected twice on 13 April 2017 (sample M1) and 16 May 2017 (sample M2) from Vinacafe Bien Hoa JSC, Long Thanh Industrial Park, Dong Nai Province, Vietnam. Wastewater was immediately used for experiments or stored at 3C. The characteristics of the coffee raw wastewater are given in Table 1.

Table 1. Characteristics of raw coffee wastewater (CFW) samples

\begin{tabular}{cccc}
\hline Parameter & Unit & Sample (M1) & Sample (M2) \\
\hline $\mathrm{pH}$ & - & 10 & 6 \\
Color & $\mathrm{Pt}-\mathrm{Co}$ & 7958 & 6700 \\
$\mathrm{COD}$ & $\mathrm{mg} / \mathrm{L}$ & 2912 & 3120 \\
$\mathrm{TSS}$ & $\mathrm{mg} / \mathrm{L}$ & 2750 & 5600 \\
BOD $_{5}$ & $\mathrm{mg} / \mathrm{L}$ & 874 & 1302 \\
Total nitrogen & $\mathrm{mg} / \mathrm{L}$ & - & 64.45 \\
\hline
\end{tabular}

M1\&M2: The wastewater was collected on 13 April, 2017 and 16 May, 2017, respectively, from the plant.

\subsection{Materials, apparatus, and methods}

Chemicals including $\mathrm{K}_{2} \mathrm{Cr}_{2} \mathrm{O}_{7}, \mathrm{FeSO}_{4} .7 \mathrm{H}_{2} \mathrm{O}, \mathrm{Fe}\left(\mathrm{NH}_{4}\right)_{2}\left(\mathrm{SO}_{4}\right)_{2} .6 \mathrm{H}_{2} \mathrm{O}, \mathrm{NaOH}, \mathrm{H}_{2} \mathrm{SO}_{4}$, and $\mathrm{NaCl}$ were of analytical grade. $\mathrm{pH}$ was measured using PHS-550 (Taiwan). Absorption was measured using a Photolab 6100 VIS spectrophotometer (Germany).

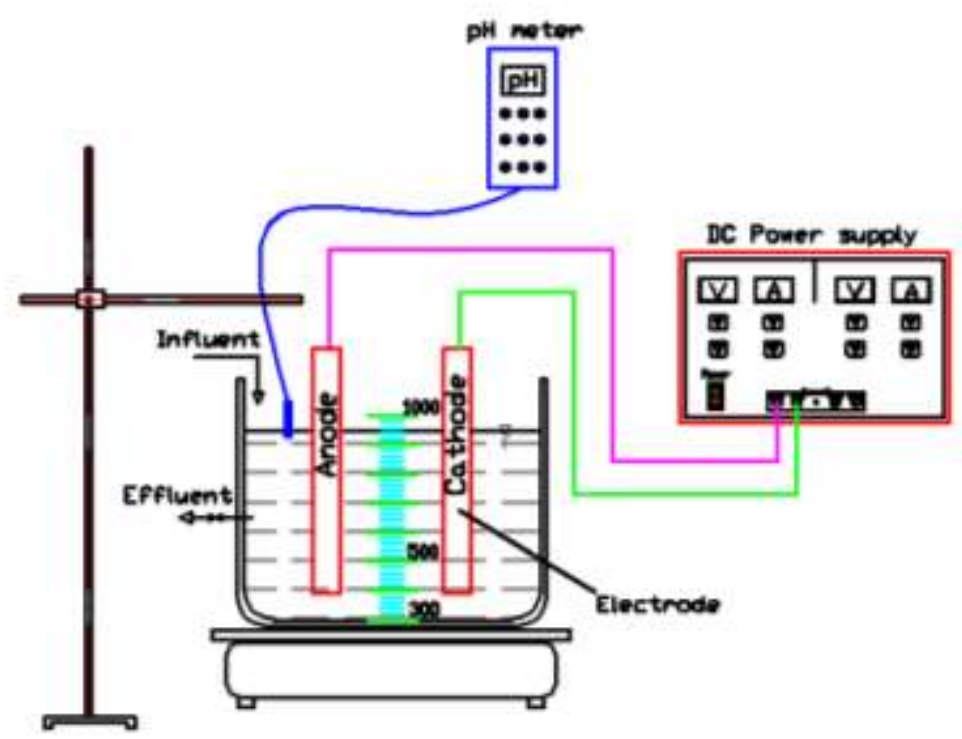

Figure 1. Schematic diagram of experimental setup

Treatment of coffee wastewater was performed using a 1-L batch cell made of glass (Figure 1). A couple of aluminum-aluminum (Al-Al) or aluminum-titanium (Al-Ti) plate electrodes with effective area of each electrode of $26 \mathrm{~cm}^{2}$ was placed vertically in the cell and connected to a DC power supply. Samples with the volume of $15 \mathrm{~mL}$ were taken from sampling point on the electrocoagulation cell at certain operating times for different parameter analyses. The 
treatment process was separately conducted at various voltages (5-30 V), $\mathrm{pH}$ (5-8), electrolyte concentrations $(\mathrm{NaCl})(0.05-0.4 \mathrm{~g} / \mathrm{L})$, inter-electrode distances $(1-5 \mathrm{~cm})$, and rotation speeds $(0$, 30, 100 and $200 \mathrm{rpm}$ ), with/without settling of EC treated wastewater. The optimum condition was then selected, and at this condition, the removals of $\mathrm{COD}, \mathrm{BOD}_{5}$, true color, total suspended solid (TSS), total nitrogen (TN) and electrode weight loss were measured.

COD and true color were analyzed based on the standard method for examination of water and wastewater (Clesceri et al., 1998), using closed reflux colorimetric method for COD and colorimetry for color at wavelength of $455 \mathrm{~nm}$. BOD 5 , TN, and TSS were analyzed according to TCVN 6001-1: 2008, TCVN 6638:2000, and TCVN 6625:2000, respectively. All these parameters were analyzed at Consultancy Center of O.S.H \& Environmental Technology (HCMC, Vietnam). Removal efficiencies of different parameters were calculated based on the Equation 1. Energy consumption for removal of one kg of COD was calculated based on Equation 2. Weight loss of electrode was calculated based on the Equation 3.

$$
H(\%)=\left(C_{0}-C_{1}\right) \times 100 / C_{0}
$$

Where $H$ is removal efficiency (\%); $\mathrm{C}_{0}, \mathrm{C}_{1}$ are initial and final concentrations of COD, $\mathrm{BOD}_{5}, \mathrm{TSS}$, $\mathrm{TN}$, and color.

$$
E=\frac{U \times I \times t \times 1000}{60 \times\left(C_{0}-C_{1}\right) \times V}
$$

Where $E$ is energy consumption (kWh/kgCOD); $U$ is applied voltage ( $V$ ); I is applied current (A); $t$ is time for EC treatment (min); $V$ is the volume of wastewater to be treated (L); $C_{0}, C_{1}$ are initial and final COD concentrations (mg/L).

$$
\Delta m=m_{\mathrm{o}}-m_{1}(\mathrm{mg})
$$

Where $m_{\mathrm{o}}$ and $m_{1}$ are the initial and final weights of electrode (mg).

\section{Results}

\subsection{Effect of applied voltage}

Effects of applied potential on the performance of CFW treatment with $\mathrm{Al}-\mathrm{Al}$ and $\mathrm{Al}-\mathrm{Ti}$ electrodes were investigated in the range of 5-40 V for 120 minutes. In these tests, the initial $\mathrm{pH}$ of solution was controlled at 6 , the electrode distance was fixed at $2 \mathrm{~cm}$, and the experiment was conducted without the addition of electrolyte and rotation. For control sample without applied current, the change of COD and color was insignificant for 120 min (data not shown).

Figure 2 illustrates the removals of COD and color for sample M2 as a function of retention time under different applied potentials. It can be seen that for a certain voltage, the removal of COD and color were fast at the beginning, then slow before reaching to almost unchanged values. There is a tendency that color was removed faster comparted to COD. The increase in cell voltage (from 5 to $30 \mathrm{~V}$ ) resulted in the significant improvement of both color and COD removals. 

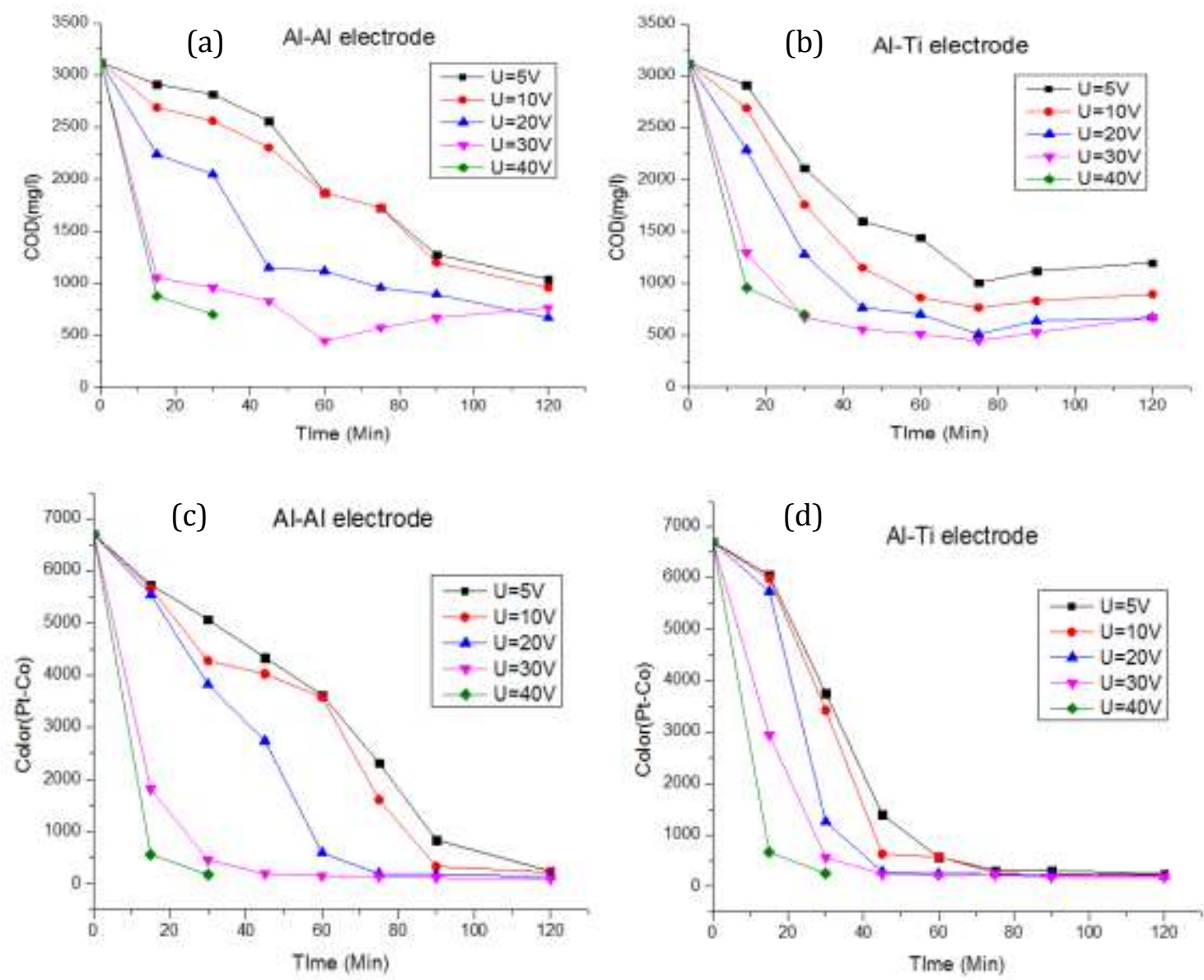

Figure 2. Removal of COD (a) and color (c) using an Al-Al electrode; Removal of COD (b) and color (d) using Al-Ti electrode (M2).

The higher applied voltage, which means the higher current density as can be seen in Figure 3 , can increase the extent of anodic dissolution and in turn results in a greater amount of hydroxide ions (Sahu et al., 2014) as the following reactions:

$$
\begin{aligned}
& \mathrm{Al}-3 \mathrm{e} \rightarrow \mathrm{Al}^{3+} \\
& \mathrm{Al}^{3+}+3 \mathrm{H}_{2} \mathrm{O} \rightarrow \mathrm{Al}(\mathrm{OH})_{3}+3 \mathrm{H}^{+}
\end{aligned}
$$

Therefore, it can be explained that the higher applied potential resulted in more abundance of aluminum hydroxides in the solution serving for coagulation processes thus leading to more efficient COD and color decontamination.

In addition, with increasing current density, the flocculation - metal hydroxide from solution by floatation may increase in an increase of bubble generation of $\mathrm{O}_{2}$ and $\mathrm{H}_{2}$ from anode and cathode, respectively (Kobya et al., 2016). It means that flocculation will improve its flotation, which helps to remove sludge after EC process and influence the treatment efficiency and operating cost of the EC. 
However, it should be mentioned that the increase in cell voltage to $40 \mathrm{~V}$ was found to cause significant heat generation in the reactor and hence the operation was stopped after just 30 minutes. This is in agreement with the previous study by Sahu et al. (2014)which found that a very high current density was not beneficial for an electrocoagulation process. In some cases, the COD values tented to increase after reaching highest removal points, that could be possibly ascribed to the desorption of adsorbed pollutants back into the solution (Khandegar and Saroha, 2013). This may indicate that an inappropriate long electrocoagulation time resulted in not only waste of energy supply but also reduction in the treatment performance.
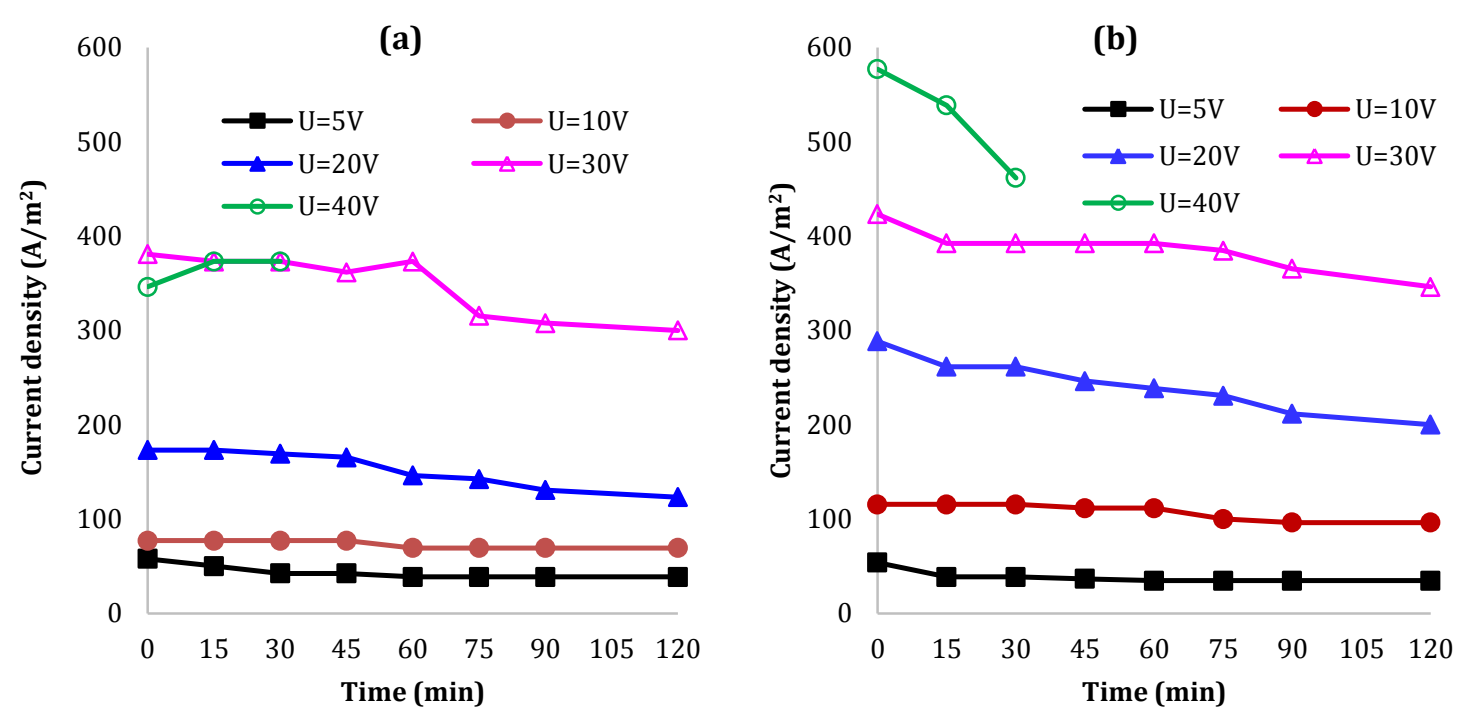

Figure 3. Change of current density by time at different applied voltages (M2) (a) Al-Al electrodes, (b) AlTi electrodes.

Both for COD and color removal, $\mathrm{Al}-\mathrm{Ti}$ electrodes showed faster removals compared to $\mathrm{Al}-\mathrm{Al}$ electrodes at $U=5,10$, and $20 \mathrm{~V}$. This would be due to the higher current densities obtained by $\mathrm{Al}-\mathrm{Ti}$ electrodes than by $\mathrm{Al}-\mathrm{Al}$ electrodes (Figure 3), indicating that the operation using $\mathrm{Al}-\mathrm{Ti}$ electrodes consumed higher electrical energy than that using $\mathrm{Al}-\mathrm{Al}$ electrodes. It means that there are more amount of hydroxide ions in Al-Ti electrodes serving for coagulation processes thus leading to more efficient COD and color decontamination. However, at $U=30$ and $40 \mathrm{~V}$, the trend of removals were similar for both types of electrodes. It could be due to the charge $(Q=I \times$ $t / V$ where I $(A)$ : current, $t(\mathrm{~min})$ : time of treatment and $V(\mathrm{~L})$ : volume of the treated wastewater) supplied at both voltages were high enough (from 15 to $31 \mathrm{~A} \mathrm{min/L)} \mathrm{that} \mathrm{the} \mathrm{change} \mathrm{in} \mathrm{voltage}$ (and current density) did not much affect COD and color removals. This is in agreement with the previous study by Sahu et al. (2014) which found that a very high current density was not beneficial for an electrocoagulation process. According to the obtained results, we gave the priority for COD removal and selected the working conditions for the treatment of coffee wastewaters (M2) were as followings: retention time of $60 \mathrm{~min}$ for Al-Al electrode, $75 \mathrm{~min}$ for $\mathrm{Al}-\mathrm{Ti}$ anodes and applied voltage of $30 \mathrm{~V}$. 


\subsection{Effect of initial pH}

Initial $\mathrm{pH}$ of solution has a significant impact on the COD and color removals since it relates to the formation of the state of chemical species in solution and the solubility of reaction products (Sahu et al., 2014). Thus, in this study, we investigated the influence of initial pH (from 5 to 9) on the performance of the CFW using Al-Al electrodes (Figure 4a) and Al-Ti electrodes (Figure 4b) (M2). It can be observed that the highest COD removal efficiencies were obtained in slightly acidic media ( $\mathrm{pH} \mathrm{6}$ ); accordingly the effluent COD and color were recorded at $448 \mathrm{mg} / \mathrm{l}$ and $168 \mathrm{Pt}$-Co with Al-Al electrodes, $448 \mathrm{mg} / \mathrm{l}$ and $198 \mathrm{Pt}$-Co with Al-Ti electrodes (for M2). This is due to the fact that the $\mathrm{Al}(\mathrm{OH})_{3}$ precipitates and polymeric species $\mathrm{Al}_{13}(\mathrm{OH})_{34^{5+}}$, which were favorable for EC process, were formed in the $\mathrm{pH}$ range of 6-8 at the anode according to Pourbaix diagram of aluminum in aqueous solution (Lekhlif et al., 2014). The previous studies (Shen et al., 2003; Adhoum \& Monser, 2004) reported that the treatment efficiency was decreased in strong acidic medium (pH less than 6) or heavy alkaline medium (higher than 8). This trend can be attributed to the amphoteric behavior of aluminum that leads to soluble $\mathrm{Al}^{3+}$ and $\mathrm{Al}(\mathrm{OH})^{2+}$ cations at $\mathrm{pH}<6$ and to $\mathrm{Al}(\mathrm{OH})_{4}^{-}$ions at $\mathrm{pH}>8$ according to the following reaction:

$$
\mathrm{Al}(\mathrm{OH})_{3}(\mathrm{~s})+\mathrm{OH}^{-} \rightarrow \mathrm{Al}(\mathrm{OH})^{4-} \quad(\mathrm{pH}>9)
$$

The presence of these soluble species was reported to be disadvantageous for electrocoagulation process (Kobya et al., 2006). Therefore, for efficient removals of COD and color, the optimum pH was defined to be 6 , which is closed to the real condition of coffee wastewater in the practical treatment process.
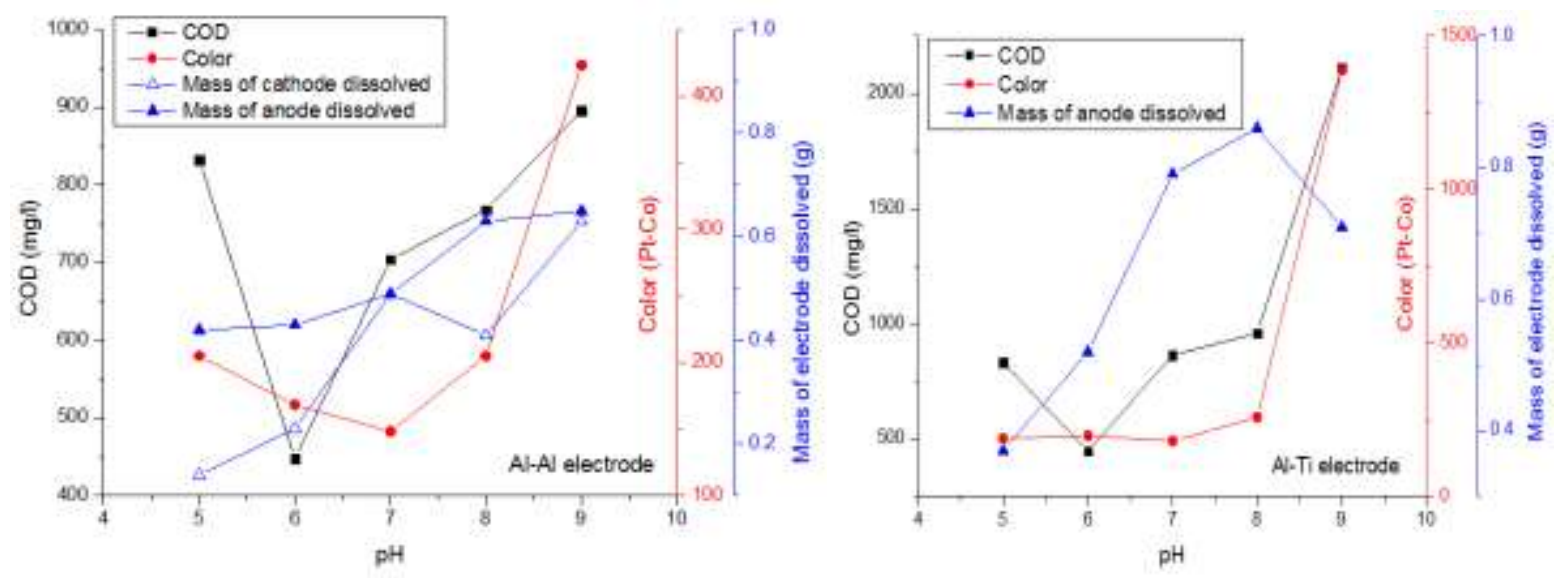

Figure 4. Effect of $\mathrm{pH}$ on COD, color in the effluents and the electrodes' weight loss (M2) (a) Al-Al electrodes, (b) Al-Ti electrodes

\subsection{Effect of inter-electrode distance}

The electrostatic field between the two electrodes depends on the distance between the anode and cathode; thus, an optimum inter-electrode distance needed to be defined for obtaining good treatment efficiencies. Figure 5 illustrates changes in current density and removal efficiencies of COD and color as functions of electrode distance. Operating condition was with the applied voltage of $30 \mathrm{~V}$, initial $\mathrm{pH}$ at 6, and treatment for $60 \mathrm{~min}$ (Al-Al electrodes) and 
75 min (Al-Ti electrodes). It can be seen that the trends of performance of $\mathrm{Al}-\mathrm{Al}$ and $\mathrm{Al}-\mathrm{Ti}$ electrodes in this case appeared quite similar. When varying the electrode distance from 1 to 5 $\mathrm{cm}$, the current density decreased from about 567 to $125 \mathrm{~A} / \mathrm{m}^{2}$ (Al-Al electrode) and 627 to 138 $\mathrm{A} / \mathrm{m}^{2}$ (Al-Ti electrodes). The highest removal efficiency of COD (81\%) was achieved at an interelectrode distance of $2 \mathrm{~cm}$ while either a shorter $(<2 \mathrm{~cm})$ or longer electrode distance $(>2 \mathrm{~cm})$ offered lower COD removal efficiencies. This is due to the fact that hydroxide ions, which were produced from restrained anode collision of pollutants in case of shorter inter-electrode distances because of the excessive formation of hydroxide ions in short periods of time (Daneshvar et al., 2004). Otherwise, the electrostatic also caused less moving of these ions in further increasing the distance between the electrodes. This means that the decrease of electrostatic attraction in an increase of electrode distance leads to inducing in the less formation of flocs. In addition, these results can also be explained by the Ohmic potential (OP) drop between the anode and the cathode (Vasudevan et al., 2011):

$$
\eta_{I R}=\frac{I \times d}{A \times k}
$$

Where $I$ is the current $(A), d$ is the distance between the cathode and the anode $(\mathrm{m}), A$ is the active anode surface $\left(\mathrm{m}^{2}\right), k$ is the specific conductivity $\left(10^{3} \mathrm{mS} / \mathrm{m}\right)$. According to this equation, a longer inter-electrode distance caused increase in solution resistance, and thus resulted in increased potential loss and reduced treatment efficiencies (Sahu et al., 2014).

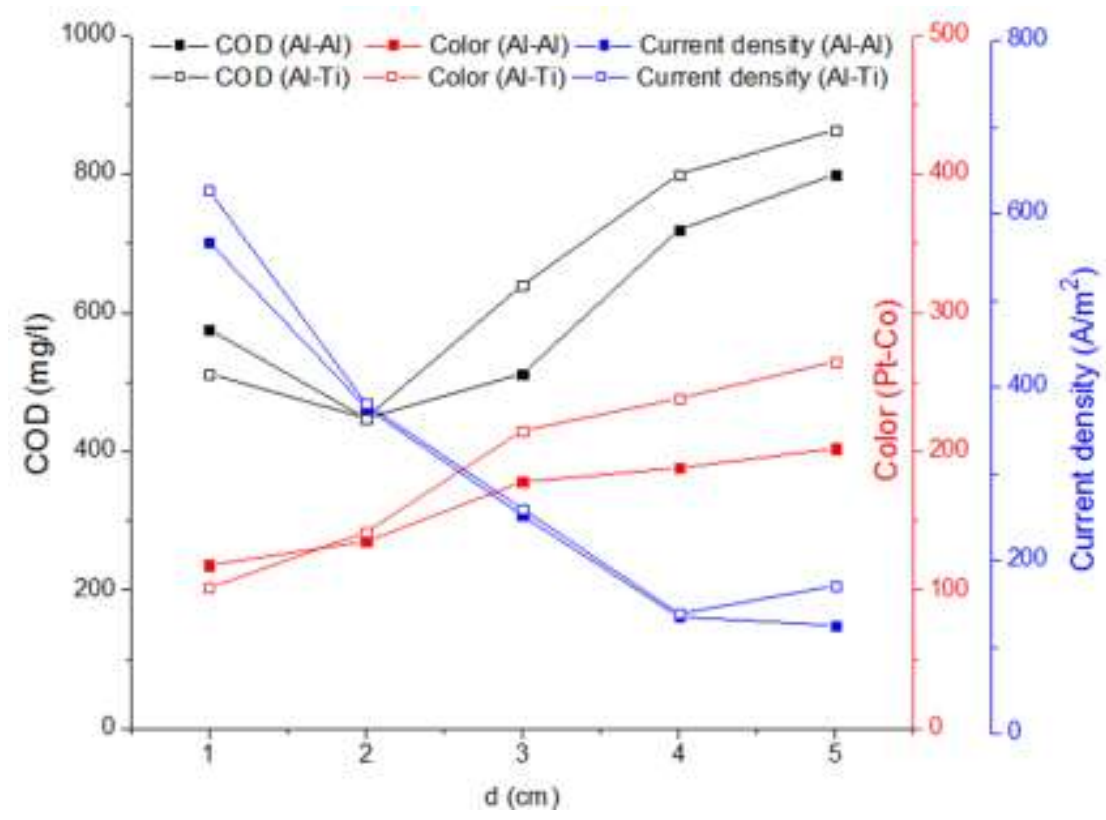

Figure 5. Effect of electrode distance on COD and color removal by Al- $\mathrm{Al}$ and Al-Ti electrodes (M2).

\subsection{Effect of solution conductivity and agitation speed}

Conductivity of the solution is a very important parameter in EC for the removal of pollutants (Khandegar and Saroha, 2013). According to Bayramoglu et al. (2004) an increase in the current density with an increase in the conductivity of the solution is cable of oxidizing 
pollutants due to the present of $\mathrm{OCl}^{-}$releasing from anode as the addition of NaCl. Moreover, it is recommended to ensure an efficient EC in water treatment when the electrolyte contains more than $200 \mathrm{mg} / \mathrm{dm}^{3}$ of $\mathrm{Cl}^{-}$(Holt et al., 2005).

Table 2 shows the effect of $\mathrm{NaCl}$ concentration on the removal efficiencies of COD and color for Al-Al (experiment No. 1-4) and Al-Ti electrodes (experiment No. 5-8). Interestingly, the results deduced that the addition of $\mathrm{NaCl}$ in the range of $0.05-0.2 \mathrm{~g} / \mathrm{L}$ did not improve the removal efficiencies of both $\mathrm{COD}$ and color to compare with no addition of $\mathrm{NaCl}$, though current density was increased. It is possibly due to the sufficient amount of $\mathrm{NaCl}$ already existing in raw $\mathrm{CFW}$. In addition, adding $\mathrm{NaCl}$ caused a significant increase in solution temperature after $30 \mathrm{~min}$ of treatment. For Al-Al electrodes, the temperature was $39,58,60$, and $75^{\circ} \mathrm{C}$ with the addition of $0,0.05,0.1$, and $0.2 \mathrm{mg} / \mathrm{L} \mathrm{NaCl}$, respectively. Similarly, the temperature was $39,59,63$, and $79^{\circ} \mathrm{C}$ for Al-Al electrodes. This increasing temperature maybe not beneficial for the treatment because it possibly induced excess mixing and also desorbed adsorbed pollutants back into the solution.

Table 2. Experimental results obtained using different electrolytic concentrations $(\mathrm{NaCl})$ and agitation speeds (M2)

\begin{tabular}{lcccccccc}
\hline Experiment No. & 1 & 2 & 3 & 4 & 5 & 6 & 7 & 8 \\
\hline Electrode material & $\mathrm{Al}-\mathrm{Al}$ & $\mathrm{Al}-\mathrm{Al}$ & $\mathrm{Al}-\mathrm{Al}$ & $\mathrm{Al}-\mathrm{Al}$ & $\mathrm{Al}-\mathrm{Ti}$ & $\mathrm{Al}-\mathrm{Ti}$ & $\mathrm{Al}-\mathrm{Ti}$ & $\mathrm{Al}-\mathrm{Ti}$ \\
NaCl concentration $(\mathrm{g} / \mathrm{L})$ & 0 & 0.05 & 0.1 & 0.2 & 0 & 0.05 & 0.1 & 0.2 \\
Current density $\left(\mathrm{A} / \mathrm{m}^{2}\right)$ & 330 & 346 & 403 & 453 & 370 & 384 & 462 & 500 \\
\% COD removal & 86 & 75 & 77 & 79 & 86 & 74 & 79 & 77 \\
\% Color removal & 97 & 97 & 97 & 94 & 97 & 97 & 97 & 96 \\
\hline & & & & & & & & \\
\hline Experiment No. & 7 & 8 & 9 & 10 & 11 & 12 & 13 & 14 \\
\hline Electrode material & $\mathrm{Al}-\mathrm{Al}$ & $\mathrm{Al}-\mathrm{Al}$ & $\mathrm{Al}-\mathrm{Al}$ & $\mathrm{Al}-\mathrm{Al}$ & $\mathrm{Al}-\mathrm{Ti}$ & $\mathrm{Al}-\mathrm{Ti}$ & $\mathrm{Al}-\mathrm{Ti}$ & $\mathrm{Al}-\mathrm{Ti}$ \\
Agitation speed (rpm) & 0 & 30 & 100 & 200 & 0 & 30 & 100 & 200 \\
Current density $\left(\mathrm{A} / \mathrm{m}^{2}\right)$ & 365 & 300 & 300 & 300 & 365 & 327 & 288 & 270 \\
\% COD removal & 87 & 84 & 81 & 81 & 87 & 79 & 83 & 79 \\
\% Color removal & 99 & 99 & 98 & 98 & 98 & 98 & 97 & 97 \\
\hline
\end{tabular}

Table 3. Performance of CFW treatment at the optimum operation conditions (M2)

\begin{tabular}{lccc}
\hline \multicolumn{1}{c}{ Parameters } & Unit & \multicolumn{2}{c}{ Value } \\
\hline Electrode material & - & $\mathrm{Al}-\mathrm{Al}$ & $\mathrm{Al}-\mathrm{Ti}$ \\
Current density & $\mathrm{A} / \mathrm{m}^{2}$ & 330 & 365 \\
Voltage EC $(\mathrm{U})$ & $\mathrm{V}$ & 30 & 30 \\
Electrolysis time & $\mathrm{min}$ & 60 & 75 \\
Energy consumption & $\mathrm{kWh} \mathrm{kg}^{-1} \mathrm{COD}$ & $9.54-14.24$ & $13.02-16.97$ \\
Electrode consumption & $\mathrm{g} \mathrm{electrode} \mathrm{kg-1}^{-1} \mathrm{COD}$ & $0.24-0.5$ & $0.18-0.37$ \\
Operation cost & $\$ \mathrm{~kg}^{-1} \mathrm{COD}$ & $0.83-1.49$ & $0.88-2.51$ \\
\hline
\end{tabular}

The agitation condition also contributes considerably to the proper operation of an EC system as it supports the well-mixing of solution and avoids the formation of concentration gradient in the electrolysis cell (Bensadok et al., 2008; Adamovic et al., 2016). Simultaneously, the application of high stirring speeds, however, may induce the collisions of flocs and formation 
of debris from broken flocs thus decreasing pollutant removal efficiencies (Modirshahla et al., 2008). To examine the effect of agitation speed, the experiments were performed with the initial $\mathrm{pH} \mathrm{6}$, the electrode distance of $2 \mathrm{~cm}$, cell voltage of $30 \mathrm{~V}$, time for treatment of $30 \mathrm{~min}$, and agitation speeds varied from $0 \sim 200 \mathrm{rpm}$. Table 3 shows the effect of agitation speed on the removal efficiencies of $\mathrm{COD}$ and color for $\mathrm{Al}-\mathrm{Al}$ (experiment No. 7-10) and Al-Ti electrodes (experiment No. 11-14). Surprisingly, the highest removal efficiencies of COD and color were obtained without agitation, which were $(\sim 87 \%)$ and ( $\sim 99 \%)$, respectively, for Al-Al electrodes, and $(\sim 87 \%)$ and $(\sim 98 \%)$, respectively, for Al-Ti electrodes. As the agitation speed increased from 0 to $200 \mathrm{rpm}$, the COD and color removal efficiency decreased within 0-8\%. Hence, we let the treatment system work without agitation in the next experiments.

\subsection{CFW treatment at optimum condition}

\subsubsection{Treatment efficiency}

Figure 6 shows the treatment of $\mathrm{Al}-\mathrm{Al}$ and $\mathrm{Al}-\mathrm{Ti}$ electrodes with $\mathrm{M} 1$ and $\mathrm{M} 2$ samples at the optimum operating conditions, i.e. initial $\mathrm{pH} 6$, electrode distance of $2 \mathrm{~cm}$, cell voltage of $30 \mathrm{~V}$, retention time of 90 and 60 for M1 and M2, respectively, using $\mathrm{Al}-\mathrm{Al}$ electrodes, and 120 and 75 min for M1 and M2, respectively, using Al-Ti electrodes. The system was worked without mixing and the treated wastewater was let for setting of $30 \mathrm{~min}$ before taking for analysis. The COD concentration of the effluents differed insignificantly for $\mathrm{Al}-\mathrm{Al}$ and $\mathrm{Al}-\mathrm{Ti}$ electrodes in both cases of M1 and M2, from 359-384 mg/L. The effluent color was 58 Pt-Co (M1) and 88 Pt-Co (M2) for the case of Al-Al electrodes while final color was lower 65 Pt-Co (M1) and 101 Pt-Co (M2) for the case of Al-Ti electrodes. Indeed, COD and color reached very high removal efficiencies of 86.8 and $99.3 \%$, respectively for $\mathrm{Al}-\mathrm{Al}$ electrodes, and 87.7 and $98.7 \%$ for $\mathrm{Al}-\mathrm{Ti}$ electrodes. Though the COD effluents were not achieved National technical regulation on industrial wastewater in Vietnam (40:2011, column B) (allowed value of $150 \mathrm{mg} / \mathrm{L}$ ), color of the effluents met well the regulation (allowed value of $150 \mathrm{Pt}-\mathrm{Co}$ ). In addition, the $\mathrm{BOD}_{5} / \mathrm{COD}$ of $\mathrm{CFW}$ was significantly changed from initial value of 0.42 to 0.65 after $\mathrm{EC}$ treatment (for M2 and Al-Al electrodes samples, data not shown), indicating the biodegradability improvement. Therefore, the effluents after EC process can be treated further by aerobic biological treatment.
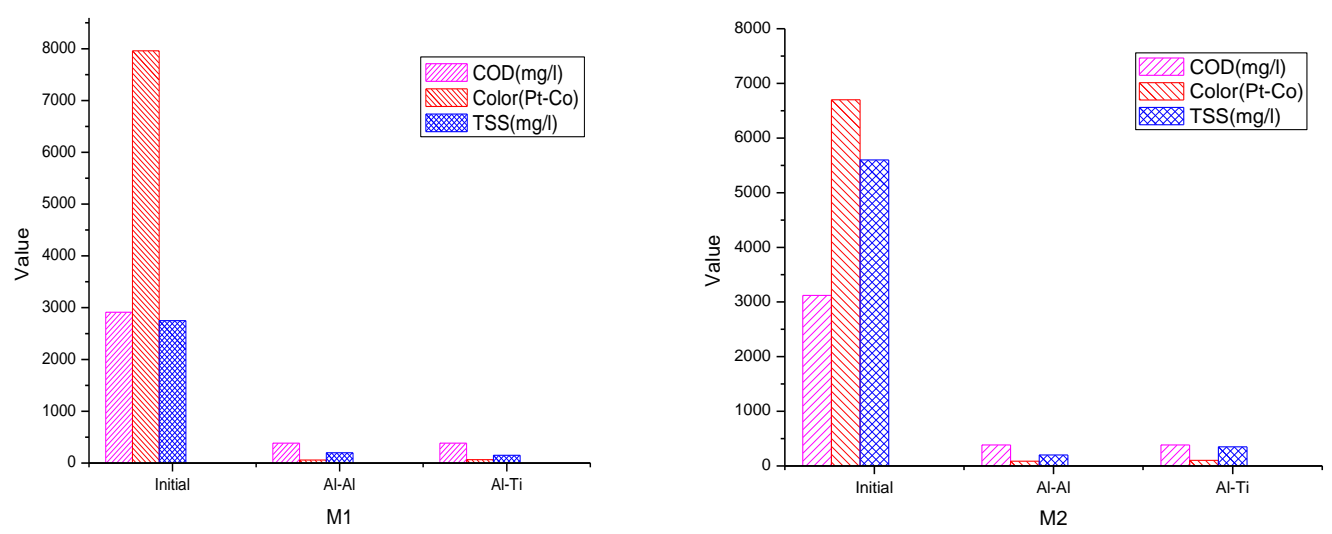

Figure 6. Summary results from the initial wastewater to the treated water at optimized conditions in terms of COD, color, TSS. 
Table 4. Comparison of differential industrial wastewater types by EC process

\begin{tabular}{|c|c|c|c|c|c|}
\hline $\begin{array}{c}\text { Type of } \\
\text { wastewater }\end{array}$ & $\begin{array}{l}\text { Operating conditions } \\
\text { (tested range) }\end{array}$ & $\begin{array}{c}\text { Electrode } \\
\text { type }\end{array}$ & $\begin{array}{l}\text { Removal } \\
\text { COD }(\%) \\
\end{array}$ & Operating cost & References \\
\hline $\begin{array}{l}\text { Coal mine } \\
\text { drainage } \\
\text { wastewater }\end{array}$ & $500 \mathrm{~A} / \mathrm{m}^{2}, 40 \mathrm{~min}, \mathrm{pH} 2.5$ & $\mathrm{Fe}$ & 28.8-99.6 & $\begin{array}{c}1.09- \\
2.184 \$ / \mathrm{m}^{3}\end{array}$ & $\begin{array}{l}\text { (Oncel et al., } \\
\text { 2013) }\end{array}$ \\
\hline \multirow{2}{*}{$\begin{array}{l}\text { Waste metal } \\
\text { cutting fluids }\end{array}$} & $60 \mathrm{~A} / \mathrm{m}^{2}, \mathrm{pH} 5.0$ & $\mathrm{Al}$ & 93 & $0.036 \$ / \mathrm{kgCOD}$ & \multirow{2}{*}{$\begin{array}{l}\text { (Kobya et } \\
\text { al., 2008) }\end{array}$} \\
\hline & $60 \mathrm{~A} / \mathrm{m}^{2}, \mathrm{pH} 7.0$ & $\mathrm{Fe}$ & 92 & $0.032 \$ / \mathrm{kgCOD}$ & \\
\hline \multirow{2}{*}{$\begin{array}{l}\text { Real dyehouse } \\
\text { wastewater }\end{array}$} & $65 \mathrm{~A} / \mathrm{m}^{2}, \mathrm{pH} 5.5$ & $\mathrm{Al}$ & 77 & $1.851 \$ / \mathrm{m}^{3}$ & \multirow{2}{*}{$\begin{array}{l}\text { (Kobya et } \\
\text { al., 2016) }\end{array}$} \\
\hline & $65 \mathrm{~A} / \mathrm{m}^{2} \mathrm{pH} 5.5$ & $\mathrm{Fe}$ & 85 & $1.562 \$ / \mathrm{m}^{3}$ & \\
\hline $\begin{array}{l}\text { Synthetic } \\
\text { textile } \\
\text { wastewater } \\
\text { (Basic } \\
\text { Red 5001 B) } \\
\end{array}$ & $30 \mathrm{~A} / \mathrm{m}^{2}, 10-20 \mathrm{~min}, \mathrm{pH} 7.0$ & $\mathrm{Fe}$ & 90 & $\begin{array}{c}0.495 \\
\mathrm{kWh} / \mathrm{m}^{3}\end{array}$ & $\begin{array}{l}\text { (Ardhan et } \\
\text { al., 2015) }\end{array}$ \\
\hline $\begin{array}{l}\text { Real textile } \\
\text { wastewater }\end{array}$ & $200 \mathrm{~A} / \mathrm{m}^{2}, 60 \mathrm{~min}, \mathrm{pH} 3.0$ & $\mathrm{Fe}$ & $90-98$ & $\begin{array}{c}69.1 \mathrm{kWh} / \mathrm{kg} \\
\mathrm{COD} \\
\end{array}$ & $\begin{array}{c}\text { (Un and } \\
\text { Aytac, 2013) }\end{array}$ \\
\hline \multirow{2}{*}{$\begin{array}{l}\text { Paint } \\
\text { manufacturing } \\
\text { company } \\
\text { wastewater } \\
\end{array}$} & & $\mathrm{Fe}$ & 93 & $0.22 \$ / \mathrm{m}^{3}$ & \multirow[b]{2}{*}{$\begin{array}{l}\text { (Akyol, } \\
2012)\end{array}$} \\
\hline & $35 \mathrm{~A} / \mathrm{m}^{2}, 15 \mathrm{~min}, \mathrm{pH} 6.95$ & $\mathrm{Al}$ & 94 & $0.15 \$ / \mathrm{m}^{3}$ & \\
\hline $\begin{array}{l}\text { Baker's yeast } \\
\text { wastewater }\end{array}$ & $80 \mathrm{~A} / \mathrm{m} 2,12.5 \mathrm{~A} / \mathrm{m}^{2}, \mathrm{pH} 4-5$ & $\mathrm{Al}$ & $48-49$ & $\begin{array}{c}0.52- \\
0.95 \$ / \mathrm{m}^{3} \\
\end{array}$ & $\begin{array}{l}\text { (Gengec et } \\
\text { al., 2012) }\end{array}$ \\
\hline $\begin{array}{l}\text { Poultry } \\
\text { slaughterhouse } \\
\text { wastewater }\end{array}$ & $10 \mathrm{~A} / \mathrm{m}^{2}, 30 \mathrm{~min}, \mathrm{pH} 3.0$ & $\mathrm{Al}$ & 85 & $3.15 \mathrm{kWh} / \mathrm{m}^{3}$ & $\begin{array}{c}\text { (Bayar et al., } \\
\text { 2011) }\end{array}$ \\
\hline $\begin{array}{l}\text { Olive mill } \\
\text { wastewater }\end{array}$ & $1 \mathrm{~A}, 45 \mathrm{~min}, \mathrm{pH} 4.3$ & $\mathrm{Al}$ & 58.7 & $0.16 \$ / \mathrm{kgCOD}$ & $\begin{array}{l}\text { (Coskun et } \\
\text { al., 2012) }\end{array}$ \\
\hline $\begin{array}{l}\text { Coffee } \\
\text { wastewater }\end{array}$ & $\begin{array}{c}\text { 35V (5-40V), } 45 \text { min }(0-60), \\
\text { pH 3.92, distance: } 1 \mathrm{~cm}, \\
\text { applied mixing }\end{array}$ & $\mathrm{Al}$ & 64 & $\mathrm{NA}^{*}$ & $\begin{array}{l}\text { (Mahesh et } \\
\text { al., 2014) }\end{array}$ \\
\hline \multirow[t]{2}{*}{$\begin{array}{l}\text { Coffee pulping } \\
\text { wastewater }\end{array}$} & $\begin{array}{c}95.9 \mathrm{~A} / \mathrm{m}^{2}, 45 \mathrm{~min}, \text { distance } \\
1 \mathrm{~cm} \text {, applied mixing }\end{array}$ & $\mathrm{Al}$ & 95 & $\begin{array}{l}3.62 \mathrm{kWh} / \mathrm{kg} \\
\mathrm{COD}\end{array}$ & \multirow{2}{*}{$\begin{array}{l}\text { (Asha and } \\
\text { Kumar, } \\
\text { 2016) }\end{array}$} \\
\hline & $\begin{array}{l}173.46 \mathrm{~A} / \mathrm{m}^{2}, 60 \mathrm{~min}, \\
\text { distance } 1 \mathrm{~cm} \text {, applied } \\
\text { mixing }\end{array}$ & $\mathrm{Fe}$ & 89 & $\begin{array}{l}45.3 \mathrm{kWh} / \mathrm{kg} \\
\mathrm{COD}\end{array}$ & \\
\hline $\begin{array}{l}\text { Instant coffee } \\
\text { wastewater }\end{array}$ & $\begin{array}{c}108.3 \mathrm{~A} / \mathrm{m}^{2}(43.4-130), 10 \\
\text { min }(4-12), \mathrm{pH} \text { 7.0 (4-10), } \\
\text { distance: } 1.5 \mathrm{~cm} \text {, settling: } 30 \\
\mathrm{~min}\end{array}$ & $\mathrm{Fe}$ & 90.4 & NA & (Bui, 2017) \\
\hline \multirow[t]{2}{*}{$\begin{array}{l}\text { Instant coffee } \\
\text { wastewater }\end{array}$} & $\begin{array}{c}330 \mathrm{~A} / \mathrm{m}^{2}(76.9-330), 60 \\
\mathrm{~min}(0-120), \mathrm{pH} 6.0(5-9), \\
\mathrm{NaCl} 0 \mathrm{~g} / \mathrm{L}(0-0.2), \text { mixing } \\
\text { speed: } 0 \mathrm{rpm}(0-200), \\
\text { settling: } 30 \mathrm{~min}\end{array}$ & $\mathrm{Al}-\mathrm{Al}$ & 87 & $\begin{array}{c}0.83-1.49 \\
\$ / \mathrm{kgCOD} \sim \\
1.18-2.09 \$ / \\
\mathrm{m}^{3}\end{array}$ & This study \\
\hline & $\begin{array}{c}365 \mathrm{~A} / \mathrm{m}^{2}(53.8-576.9), 75 \\
\mathrm{~min}(0-120), \mathrm{pH} 6.0(5-9), \\
\mathrm{NaCl} 0 \mathrm{~g} / \mathrm{L}(0-0.2), \text { mixing } \\
\text { speed: } 0 \text { rpm }(0-200), \\
\text { settling: } 30 \mathrm{~min} \\
\end{array}$ & Al-Ti & 87 & $\begin{array}{c}0.88-2.51 \\
\$ / \mathrm{kg} \mathrm{COD} \sim \\
3.05-3.27 \$ / \\
\mathrm{m}^{3}\end{array}$ & This study \\
\hline
\end{tabular}

*NA: not analyzed 


\subsubsection{Operating cost}

In this study, energy consumption of EC and electrode material costs are taken into account as major cost. The operating cost using EC can be calculated by following equation:

$$
\text { Operating Cost }=\alpha C_{\text {energy }}+\beta C_{\text {electrode }}
$$

Where $C_{\text {energy }}$ and $C_{\text {electrode, }}$ are consumption per $\mathrm{m}^{3}$ of wastewater treated; $\alpha$ and $\beta$, which given from the Vietnam market, September 2017, are as follows: electrical energy price $0.04 \$ / \mathrm{kWh}$, electrode material price $1.75 \$ / \mathrm{kg}$ for aluminum. Table 3 showed that the operating costs were determined 1.18-2.09\$/ $\mathrm{m}^{3}$ (0.83-1.49 \$/kgCOD) for Al-Al electrodes and 3.05-3.27\$/ m³ $(0.88$ $2.51 \$ / \mathrm{kg}$ COD) for Al-Ti electrodes.

The EC treatment of CFW was compared with other treatments of industrial wastewater by EC process, as listed in Table 4. It was concluded that EC treatment of CFW provided a comparable operating cost to those from other studies. It is further noted that our experiment was initially designed for the highest treatment efficiency of COD, hence the selected times of electrolysis were higher than those of previous studies. In practice, if EC process is applied as pre-treatment, it can be performed for shorter times, e.g. $30 \mathrm{~min}$, for reducing operation cost. As can be seen from Figure 2, if the EC treatment was stopped for $30 \mathrm{~min}$, effluent COD concentrations were already lower than $1000 \mathrm{mg} / \mathrm{L}$. Hence, the pre-treated CFW can be effectively treated by biological treatment in the next step for completing removal of pollutants.

\subsection{Kinetics of coffee wastewater in electrocoagulation}

Electrocoagulation (EC) involves the adsorption of pollutants on the solid formed after electrochemical dissolution of the aluminum electrodes. The removal of COD is similar to conventional adsorption except for the generation of flocs (Kobya et al., 2006; Benaissa et al., 2016). In order to investigate the kinetic mechanisms which control the EC process in the treatment of CFW, the pseudo-first-order and pseudo-second order models were tested. The pseudo-first-order equation is expressed as following:

$$
\mathrm{d} C / \mathrm{dt}=k_{1} C
$$

Where $\mathrm{C}_{\mathrm{COD}}$ represents the COD (mg/L) or color (Pt-Co), t represents retention time (min), $k_{1}$ represents the rate constant $\left(\mathrm{min}^{-1}\right)$.

The pseudo-second-order adsorption kinetic rate equation is given as following:

$$
\mathrm{d} C / \mathrm{dt}=k_{2}(C)^{2}
$$

Where $\mathrm{C}_{\mathrm{COD}}$ represents the COD (mg/L) or color (mg/L Pt-Co), $t$ represents retention time (min), $k_{2}$ represents the rate constant $\left(\mathrm{L} \mathrm{mg}^{-1} \mathrm{~min}^{-1}\right)$.

A kinetic analysis was conducted by fitting the time-course performance data with the pseudo first and second order kinetics as shown in Table 5 where the rate coefficients and $\mathrm{R}^{2}$ values for different cell voltages are summarized. The data were correlated better with the first order kinetic model ( $R^{2}$ from 0.87-0.99) than with second order kinetic model $\left(R^{2}\right.$ from 0.75 0.97). Hence, the first order kinetic model is recommended for the description of the COD and color removal kinetics by the EC system at different cell voltages from 5 to $30 \mathrm{~V}$. 
Table 5. Kinetics rate constant for COD and color removal by Al-Al electrodes at different cell voltages (M2)

\begin{tabular}{cccccc}
\hline Parameter & Cell voltage & \multicolumn{2}{c}{ First -order kinetic model } & \multicolumn{2}{c}{ Second-order kinetic model } \\
\cline { 3 - 6 } & $(\mathrm{V})$ & $\mathrm{k}_{1} \times 10^{-2}\left(\mathrm{~min}^{-1}\right)$ & $\mathrm{R}^{2}$ & $\mathrm{k}_{2} \times 10^{-5}\left(\mathrm{~L} \mathrm{mg}^{-1} \mathrm{~min}^{-1}\right)$ & $\mathrm{R}^{2}$ \\
\hline COD & 5 & 0.69 & 0.99 & 0.4 & 0.95 \\
& 10 & 0.91 & 0.87 & 0.6 & 0.84 \\
& 20 & 1.15 & 0.96 & 1.0 & 0.89 \\
& 30 & 1.47 & 0.97 & 2.0 & 0.89 \\
\hline Color & 5 & 0.87 & 0.92 & 0.2 & 0.97 \\
& 10 & 2.48 & 0.97 & 2.0 & 0.75 \\
& 20 & 2.37 & 0.96 & 2.1 & 0.85 \\
& 30 & 4.08 & 0.93 & 10.0 & 0.89 \\
\hline
\end{tabular}

\section{Conclusion}

The electrocoagulation process were found potentially as pre-treatment to efficiently remove COD and color from instant coffee wastewater. The performance of the EC system depended significantly on the cell voltage, operating time, initial $\mathrm{pH}$, and inter-electrode distance. However, mixing and addition of electrolyte were not recommended. Optimum operating conditions were found as follows: initial pH 6, cell voltage of $30 \mathrm{~V}$, inter-electrode distance of $2 \mathrm{~cm}$. The operation times were varied by types of electrodes and wastewater taken, ranged from 60-120 min when COD removal was considered as priority of treatment. Under these conditions, similar treatment performances were observed for $\mathrm{Al}-\mathrm{Al}$ and $\mathrm{Al}-\mathrm{Ti}$ electrodes, with the highest removal efficiencies of COD and color of 87 and $99 \%$, respectively. The operating cost of EC based treatment process for Al-Al electrodes was $0.83-1.49 \$$ per $\mathrm{kg}$ COD which was lower compared to that of Al-Ti electrodes, i.e. 0.88-2.51\$ per kg COD. In addition, $\mathrm{BOD}_{5} / \mathrm{COD}$ was increased from initial value of 0.42 to 0.65 , indicating the increase of biodegradability of treated wastewater. The obtained results prove that EC setup with the simple design and easy operation mode in this study is a promising alternative, especially as an effective pre-treatment, for the practical treatment of coffee wastewater. In the future study, electrocoagulation treatment of coffee wastewater can be investigated with shorter times of treatment for lowering operating cost.

\section{Acknowledgement}

We thank student, Mr. Nguyen Minh Khanh for his kindly help in sampling and analysis. This work is supported by Center of Science and Technology Development for Youth, in HCM city.

\section{References}

Adamovic, S., Prica, M., Dalmacija, B., Rapajic, S., Novakovic, D., Pavlovic, Z., Maletic, S. (2016). Feasibility of electrocoagulation/flotation treatment of waste offset printing developer based on the response surface analysis. Arabian Journal of Chemistry, 9(1), 152-162.

Adhoum, N., Monser, L. (2004). Decolourization and removal of phenolic compounds from olive mill wastewater by electrocoagulation. Chemical Engineering and Processing: Process Intensification, 43(10), 1281-1287.

Akyol, A. (2012). Treatment of paint manufacturing wastewater by electrocoagulation. Desalination, 285, 91-99. 
Ardhan, N., Ruttithiwapanich, T., Songkasiri, W., Phalakornkule, C. (2015). Comparison of performance of continuous-flow and batch electrocoagulators: A case study for eliminating reactive blue 21 using iron electrodes. Sep. Purif. Technol., 146, 75-84.

Asha, G., Kumar, B. M. (2016). Comparison of aluminum and iron electrodes for cod reduction from coffee processing wastewater by electrocoagulation process. Journal of Scientific Research and Reports, 1-10.

Bayar, S., Yıldız, Y. Ş., Yılmaz, A. E., İrdemez, Ş. (2011). The effect of stirring speed and current density on removal efficiency of poultry slaughterhouse wastewater by electrocoagulation method. Desalination, 280(1-3), 103-107.

Bayramoglu, M., Kobya, M., Can, O. T., Sozbir, M. (2004). Operating cost analysis of electrocoagulation of textile dye wastewater. Sep. Purif. Technol., 37(2), 117-125.

Benaissa, F., Kermet-Said, H., Moulai-Mostefa, N. (2016). Optimization and kinetic modeling of electrocoagulation treatment of dairy wastewater. Desalination and Water Treatment, 57(13), 5988-5994.

Bensadok, K., Benammar, S., Lapicque, F., Nezzal, G. (2008). Electrocoagulation of cutting oil emulsions using aluminum plate electrodes. J. Hazard. Mater., 152(1), 423-430.

Bui, H. M. (2017). Optimization of electrocoagulation of instant coffee production wastewater using the response surface methodology. Polish Journal of Chemical Technology, 19(2), 67-71.

Clarke, R. J. (2012a). Coffee: Volume 1: Chemistry. Springer Netherlands.

Clarke, R. J. (2012b). Coffee: Volume 2: Technology. Springer Netherlands.

Clesceri, L. S., Eaton, A. D., Greenberg, A. E., Association, A. P. H., Association, A. W. W., Federation, W. E. (1998). Standard Methods for the Examination of Water and Wastewater. American Public Health Association.

Coskun, T., İlhan, F., Demir, N. M., Debik, E., Kurt, U. (2012). Optimization of energy costs in the pretreatment of olive mill wastewaters by electrocoagulation. Environ. Technol., 33(7), 801-807.

Daneshvar, N., Sorkhabi, H. A., Kasiri, M. (2004). Decolorization of dye solution containing Acid Red 14 by electrocoagulation with a comparative investigation of different electrode connections. J. Hazard. Mater., 112(1-2), 55-62.

Espinoza-Quinones, F. R., Fornari, M. M., Módenes, A. N., Palácio, S. M., da Silva Jr, F. G., Szymanski, N., Kroumov, A. D., Trigueros, D. E. (2009). Pollutant removal from tannery effluent by electrocoagulation. Chem. Eng. J., 151(1-3), 59-65.

Feng, J.-w., Sun, Y.-b., Zheng, Z., Zhang, J.-b., Shu, L., Tian, Y.-c. (2007). Treatment of tannery wastewater by electrocoagulation. J. Environ. Sci., 19(12), 1409-1415.

Gengec, E., Kobya, M., Demirbas, E., Akyol, A., Oktor, K. (2012). Optimization of baker's yeast wastewater using response surface methodology by electrocoagulation. Desalination, 286, 200-209.

Holt, P. K., Barton, G. W., Mitchell, C. A. (2005). The future for electrocoagulation as a localised water treatment technology. Chemosphere, 59(3), 355-367.

Khandegar, V., Saroha, A. K. (2013). Electrocoagulation for the treatment of textile industry effluent - A review. J. Environ. Manage., 128, 949-963. 
Kirk, R. F., Othmer, D. F., Grayson, M. (1985). Kirk-Othmer concise encyclopedia of chemical technology. John Wiley \& Sons.

Kobya, M., Ciftci, C., Bayramoglu, M., Sensoy, M. (2008). Study on the treatment of waste metal cutting fluids using electrocoagulation. Sep. Purif. Technol., 60(3), 285-291.

Kobya, M., Gengec, E., Demirbas, E. (2016). Operating parameters and costs assessments of a real dyehouse wastewater effluent treated by a continuous electrocoagulation process. Chemical Engineering and Processing: Process Intensification, 101, 87-100.

Kobya, M., Hiz, H., Senturk, E., Aydiner, C., Demirbas, E. (2006). Treatment of potato chips manufacturing wastewater by electrocoagulation. Desalination, 190(1-3), 201-211.

Lekhlif, B., Oudrhiri, L., Zidane, F., Drogui, P., Blais, J.-F. (2014). Study of the electrocoagulation of electroplating industry wastewaters charged by nickel (II) and chromium (VI). J. Mater. Environ. Sci, 5(1), 111-120.

Mahesh, S., Srikantha, H., Lobo, A. L. (2014). Performance evaluation of two batch operations using electrochemical coagulation followed by sequential batch reactor in treating coffee wastewater. Int. J. Chem. Tech. Res., 6(1), 339-346.

Modirshahla, N., Behnajady, M., Mohammadi-Aghdam, S. (2008). Investigation of the effect of different electrodes and their connections on the removal efficiency of 4-nitrophenol from aqueous solution by electrocoagulation. J. Hazard. Mater., 154(1-3), 778-786.

Mollah, M. Y. A., Morkovsky, P., Gomes, J. A. G., Kesmez, M., Parga, J., Cocke, D. L. (2004). Fundamentals, present and future perspectives of electrocoagulation. J. Hazard. Mater., 114(1-3), 199-210.

Mollah, M. Y. A., Schennach, R., Parga, J. R., Cocke, D. L. (2001). Electrocoagulation (EC) - science and applications. J. Hazard. Mater., 84(1), 29-41.

Mountassir, Y., Benyaich, A., Berçot, P., Rezrazi, M. (2015). Potential use of clay in electrocoagulation process of textile wastewater: Treatment performance and flocs characterization. Journal of Environmental Chemical Engineering, 3(4), 2900-2908.

Oncel, M., Muhcu, A., Demirbas, E., Kobya, M. (2013). A comparative study of chemical precipitation and electrocoagulation for treatment of coal acid drainage wastewater. Journal of Environmental Chemical Engineering, 1(4), 989-995.

Perez, S. R., Silva, R. M. P., Boizan, M. F. (2000). Study of the anaerobic biodegradability of the wastewaters of the humid benefit of the coffee. Interciencia, 25, 386-390.

Rattan, S., Parande, A., Nagaraju, V., Ghiwari, G. K. (2015). A comprehensive review on utilization of wastewater from coffee processing. Environ Sci Pollut Res, 22(9), 6461-6472.

Sahu, O., Mazumdar, B., Chaudhari, P. K. (2014). Treatment of wastewater by electrocoagulation: a review. Environ Sci Pollut Res, 21(4), 2397-2413.

Shen, F., Chen, X., Gao, P., Chen, G. (2003). Electrochemical removal of fluoride ions from industrial wastewater. Chemical Engineering Science, 58(3-6), 987-993.

Un, U. T., Aytac, E. (2013). Electrocoagulation in a packed bed reactor-complete treatment of color and cod from real textile wastewater. J. Environ. Manage., 123, 113-119.

Vasudevan, S., Lakshmi, J., Sozhan, G. (2011). Effects of alternating and direct current in electrocoagulation process on the removal of cadmium from water. J. Hazard. Mater., 192(1), 26-34. 
Yavuz, Y., Koparal, A. S., Öğütveren, Ü. B. (2010). Treatment of petroleum refinery wastewater by electrochemical methods. Desalination, 258(1-3), 201-205.

Zodi, S., Louvet, J.-N., Michon, C., Potier, O., Pons, M.-N., Lapicque, F., Leclerc, J.-P. (2011). Electrocoagulation as a tertiary treatment for paper mill wastewater: Removal of nonbiodegradable organic pollution and arsenic. Sep. Purif. Technol., 81(1), 62-68. 